\title{
The Cosmopolitan-Parochial Divide:
}

\section{Changing Patterns of Party and Electoral Competition in the Netherlands and Beyond}

\author{
Catherine E. De Vries \\ Professor of Politics \\ Department of Government \\ University of Essex \\ catherine.devries@essex.ac.uk \\ www.catherinedevries.eu
}

\begin{abstract}
Recent election outcomes in Europe and beyond reflect a growing scepticism of open borders among the public. From the Brexit vote in the United Kingdom to the election of Donald Trump in the United States, rhetoric that is critical of the organizations facilitating policy cooperation and learning across borders as well as international trade and migration is popular among a growing segment of the electorate. Are these recent developments part of a larger trend of party and electoral change? By focusing on changing patterns in party and electoral competition in the Netherlands, this article suggests that they are. Relying on expert and voter data, it argues that party and electoral politics in the Netherlands is increasingly characterized by both an economic left-right as well as a cosmopolitan-parochial divide. While the former relates to issues of state intervention into the economy, the second refers to stances on European integration, migration and national control in international affairs. This cosmopolitan-parochial divide has become largely independent of the economic left-right dimension, and influences people's voting decisions independently of their left-right views. Interestingly, the cosmopolitan-parochial divide in the Netherlands should not necessarily be understood as a cultural backlash, but rather seems a reflection of increased economic insecurity. Although the evidence stems from the Dutch case, I suggest that the cosmopolitan-parochial divide is a useful lens through which we can understand political change in Europe more generally.
\end{abstract}

KEY WORDS Political parties, public opinion, political dimensionality, European integration, European politics, immigration, the Netherlands. 


\section{Introduction}

Election outcomes in the aftermath of the Great Recession in Europe and beyond seem to demonstrate a rising scepticism of open borders among the public. The electoral gains of populist parties and the Brexit vote in the United Kingdom to the election of Donald Trump in the United States suggest that rhetoric critical of migration, trade deals and international organizations is becoming increasingly popular with a growing segment of the electorate. The question on the minds of many experts of American and European politics is if these developments are part of a larger trend of party and electoral change, or if they merely represent short upsets from a more or less stable political equilibrium.

This question has become even more important in light of the electoral triumph of the centrist candidate Emmanuel Macron in France over his populist right rival, Marine Le Pen, and outcome of the Dutch election in 2017 where the Conservative liberal party of Prime Minister Mark Rutte was able to fight off the challenge of the populist right political entrepreneur Geert Wilders. These election outcomes were viewed by many as victories for moderate forces, and as signs that the rise of populism could be halted. For example French president Emmanuel Macron (at that time still a candidate) stated that "[t]he Netherlands is showing us that a breakthrough for the extreme right is not a foregone conclusion and that progressives are gaining 
momentum." ${ }^{1}$ By relying on expert and voter data from the Netherlands, this article suggests that these types of conclusions are somewhat premature. They fail to recognize the long-term change that party competition and elections have undergone in Europe since the 1990s.

This article suggests that there are important lessons to be learned for our understanding of European politics from the changes in Dutch politics. It highlights three empirical trends. First, while the traditional economic leftright dimension is of continued importance in the Netherlands, we have witnessed the growing significance of other issues, most notably those relating to questions of migration, European integration and international cooperation, for both parties and voters. Second, party and voter polarization over these issues has not only become increasingly linked, but also more distinct from polarization on the economic left-right. I suggest that Dutch politics has become characterized by second dimension, that I coin the cosmopolitan-parochial divide. ${ }^{2}$ This divide pits cosmopolitan parties and voters on both the left and right advocating an inclusionary and international outlook, like the Dutch Green Left or Democrats 66 for example, against parochial parties and voters on both the left and right that are increasingly

\footnotetext{
${ }^{1}$ See http://www.euronews.com/2017/03/16/sighs-of-relief-in-europe-atdutch-election-result (accessed 19th of April 2017).

${ }^{2}$ Note that Kriesi et al. $(2006,2008)$ refer to a similar set of issues as the integration-demarcation dimension and Hooghe and Marks (2017) to a transnational cleavage. I outline the differences from these existing approaches in later sections.
} 
wary of open borders and international influences, such as the Dutch Socialist Party or the Party for Freedom. Both positions on the economic left-right dimension and cosmopolitanism-parochialism divide now structure people's party choice in European and national parliamentary elections in the Netherlands. Third and finally, contrary to recent studies that view the second dimension as largely cultural in nature involving a popular backlash against cultural liberalism (most notably Inglehart and Norris 2011, 2016), I show that this is not necessarily the case in the Netherlands. The more likely driving force seems to be economic insecurity (see Hacker 2006, Hacker et al. 2013).

The findings presented here have important implications for our understanding of party and electoral competition in the Netherlands as well as in Europe more broadly. Three in particular stand out. First, the evidence suggests that the outcome of the 2017 election in the Netherlands, and others in Europe after that, by no means signifies that the populist surge has been halted. Rather it indicates that more competition between cosmopolitan and parochial political forces may lie ahead in future elections. Second, parochial positions can be found on both the left and right of the political spectrum, amongst voters of the Dutch Party for Freedom as well as Socialist Party as well as cosmopolitan ones, the Green Left and Democrats 66 for example. Third, this analysis provides important insights for the understanding the developments in other European party systems. For one, the content of the second dimension is likely to be highly context-specific, where in the 
Netherlands opposition to cultural liberalism is not the core of the second dimension, in other European countries it might be. Second, the Dutch findings may be most indicative of trends in other systems where electoral thresholds are low. These contexts most likely allows for the development of largely orthogonal second represented by a diverse set of political parties.

This article is structured as follows. First, it outlines the key results of the 2017 Dutch election result and suggests why they matter. Next, it examines the development of party positions on key policy issues in the Netherlands. The third part examines the dimensionality of Dutch public opinion. The fourth and final section concludes and discusses the implications for our understanding of party and electoral competition in Europe.

\section{Beyond the Left-Right? The 2017 Dutch Election}

The anti-immigrant and anti-EU political entrepreneur Geert Wilders set the bar high for the 2017 election in the Netherlands. At the start of the European election season of 2017, elections in France, the United Kingdom, Germany and Austria were to follow; he aimed to 'unleash a populist patriotic spring'. ${ }^{3}$ It turned out to be different. Although his party gained five seats and Prime Minister Rutte's party lost, Wilders did not meet his expectation for the

3 See http://www.ft.com/content/287fefe8-e098-11e6-8405-9e5580d6e5fb (accessed 19th of April 2017). 
election. His Party for Freedom (Partij van de Vrijheid, PVV) did not become the largest party. One of the biggest winners of the election was the Green Left (Groen Links, GL) party. Its leader, the 31-year-old Jesse Klaver had been able to infuse a sense of optimism in the campaign. His message focused on sustainability, inclusion and an overall international outlook. The Liberal Democratic D66 (Democraten 66) party mobilized similar issues that led to gains at the polls. Table 1 provides an overview of seat changes in 2017 compared to the 2012 national parliamentary election. 
Table 1: 2017 Dutch Parliamentary Election Results

\begin{tabular}{|c|c|c|}
\hline Party Name & $\begin{array}{l}\text { Number of Seats } \\
\text { (150 in total) }\end{array}$ & $\begin{array}{l}\text { Change from } 2012 \\
\text { Election }\end{array}$ \\
\hline $\begin{array}{l}\text { Volkspartij voor Vrijheid en } \\
\text { Democratie (VVD) }\end{array}$ & 33 & -8 \\
\hline $\begin{array}{c}\text { Partij voor de Vrijheid } \\
\text { (PVV) }\end{array}$ & 20 & +5 \\
\hline $\begin{array}{l}\text { Christen Democratisch } \\
\text { Appel (CDA) }\end{array}$ & 19 & +6 \\
\hline $\begin{array}{c}\text { Democraten } 66 \\
\text { (D66) }\end{array}$ & 19 & +7 \\
\hline $\begin{array}{l}\text { Groen Left } \\
\text { (GL) }\end{array}$ & 14 & +10 \\
\hline $\begin{array}{l}\text { Socialistische Partij } \\
\text { (SP) }\end{array}$ & 14 & -1 \\
\hline $\begin{array}{l}\text { Partij van de Arbeid } \\
\text { (PvdA) }\end{array}$ & 9 & -29 \\
\hline $\begin{array}{l}\text { Christen Unie } \\
(\mathrm{CU})\end{array}$ & 5 & 0 \\
\hline $\begin{array}{l}\text { Partij van de Dieren } \\
\text { (PvdD) }\end{array}$ & 5 & +3 \\
\hline 50plus & 4 & +2 \\
\hline DENK & 3 & +3 \\
\hline $\begin{array}{c}\text { Staatskundig } \\
\text { Gereformeerde Partij (SGP) }\end{array}$ & 3 & 0 \\
\hline $\begin{array}{l}\text { Forum voor Democratie } \\
\qquad(\mathrm{FvD})\end{array}$ & 2 & +2 \\
\hline
\end{tabular}

Source: These results are based on the official final results released by the Kiesraad on the $21^{\text {st }}$ of March 2017.

The Conservative Liberal party (Volkspartij voor Vrijheid en Democratie, VVD) of Prime Minister Mark Rutte, lost, but did much better than the polls had suggested. Its coalition partner the Labour Party (Partij van de Arbeid, PvdA) experienced a historic loss. The party lost 29 seats and became the $7^{\text {th }}$ party in the Dutch political landscape. The election also saw seats gains for two new parties, DENK and the Forum for Democracy (Forum voor Democratie, FvD). The latter is a fierce anti-EU party, while the former is 
a pro-immigrant party founded by two former parliamentarians of the Labour party from Turkish heritage who disagreed with the harsher tone on immigration of the party in recent years. ${ }^{4}$

The election result was largely viewed in the international media as a victory for moderate forces. This is perhaps not quite an accurate description of the outcome. Indeed, progressive forces like the GL and D66 gained, but mostly at the expense of the PvdA. Equally important for the result was that the VVD as well as Christian Democrats (Christen Democratisch Appel, CDA) pandered towards Wilders' anti-immigrant and anti-EU message. For example, on the $23^{\text {rd }}$ of January Prime Minister Mark Rutte in an unprecedented move placed an ad directed to all Dutch people in the big national newspapers. The tone of the ad was harsh. 'Newcomers' as the prime minister called them were told to comply with Dutch norms or values or 'otherwise bugger off' (Rutte 2017). Wilders' party might not have become the biggest political force, but many of his stances have become part-and-parcel of the political mainstream on the right.

The election result can be seen as significant in two respects. First, it signifies the tremendous fragmentation of the Dutch political landscape. Thirteen parties are represented in parliament and a governing coalition needs to consist of at least four parties. This makes the task of governing and drafting and passing legislation through parliament extremely tricky. Second,

\footnotetext{
${ }^{4}$ For more information see: https://www.bewegingdenk.nl/.
} 
the outcome signifies the dwindling of mainstream political forces, like the Labour Party for example, that have given way to the rise of parties that mobilize on other issues than the economic left-right, such as immigration, the environment or the EU. Moreover, many new parties have quite distinctive issue profiles focusing on animal's rights or the interests of the elderly for example. These consequences of more fragmentation and the growing significance of issues beyond the left-right are indicative of larger trends in the Dutch political landscape that started in the late 1990s. This is the topic this study turns to next.

\section{Party Positioning in the Netherlands beyond the Left-Right: The}

\section{Cosmopolitan-Parochial Divide}

Party competition, at least in advanced industrial democracies in Europe, is generally perceived to consist of two dimensions (see De Vries and Marks 2012 for an overview). Scholars use a variety of terms to denote these two dimensions, the materialism versus post-materialism (Inglehart 1990), the old versus new politics (Dalton 2002), the interest versus values (Tavits and Potter 2015), the left/right versus libertarian/authoritarian (Kitschelt 1994), the left/right versus GAL/TAN dimensions (Hooghe et al 2002), the cultural versus economic demarcation and integration dimensions (Kriesi et al. 2006, 2008) or the left/right versus populism-liberal cosmopolitanism (Inglehart and 
Norris 2016) for example. What these diverse labels have in common is that they rely on a general distinction between a largely economic dimension and largely non-economic dimension. While the content of the economic dimension is more or less clear and relates to collective questions about state intervention in the economy (for a critique see De Vries et al. 2013), the content of the noneconomic dimension is much more diverse. For some it relates primarily to societal value divides based on tradition, religion, sexuality or the environment, for others it also relates to migration or European integration.

The different emphasis may in part come from a time-specific focus. Hanspeter Kriesi and his colleagues $(2006,2008)$ in their seminal work on the topic for example suggest that the content of the cultural dimension has changed in recent years. While "[i]n 1970s this dimension was dominated by issues linked to cultural liberalism", "[o]ver the following decades, new issues have been integrated" and "[t]he most important of these [being] immigration." (Kriesi et al. 2006: 950). Marks and colleagues (2006) suggest that the second dimension is also context-specific. Important differences exist between Western and Central-Eastern Europe for example.

The linkage to issues of European integration has also become a matter of contention. While conflict over Europe was initially seen as largely independent of the dominant dimensions of political conflict (Gabel and Anderson 2002; Hix and Lord 1997), in the early 2000s authors suggested that issues regarding European integration were linked to the left-right dimension 
albeit not in a straightforward way (Hooghe et al. 2002; Marks and Wilson 2000). Within this literature, the relationship between left-right placement and support for European integration is described as the 'inverted U-curve' (Hooghe et al. 2002: 968). The inverted U-curve indicates that parties of the ideological mainstream, i.e. conservative, social and Christian democratic, are generally supportive of the integration process, as they have frequently been part of governing coalitions throughout Western Europe and were therefore largely responsible for the course of integration. Extreme left- and right-wing extremist parties, however, most strongly oppose it, albeit for different reasons (Hooghe et al. 2002, De Vries and Edwards 2009). While left-wing extremist parties oppose integration in Europe on the basis of the neoliberal character of the project and its negative influence on the welfare state, the extreme right opposes intra-EU migration and aim to protect national sovereignty (De Vries and Edwards 2009). More recent approaches suggest that party stances towards immigration, the EU and international trade have been subsumed in a transnational cleavage which has its focal point in 'the defense of national political, social, and economic ways of life against external actors who penetrate the state by migrating, exchanging goods, or exerting rule.' (Hooghe and Marks 2017: 3).

This quick review of the literature on party positioning suggests that scholars argue that political space is likely two-dimensional in nature consisting of a relatively stable economic left-right dimension and a second 
dimension of which the issue content is highly flexible both across countries and within countries over time. The issues relating to immigration and European integration have been identified as the key drivers of change in dimensionality in recent years. Yet, the way in which these issues are linked with, or in fact orthogonal to, the economic left-right is a matter of extensive scholarly debate. Moreover, this is likely to differ across countries based on institutional characteristics that affect party and electoral competition, and specific societal conditions and events, such as levels of immigration for example. Ultimately, the question of how the issues of European integration and immigration fit onto existing dimensions of party competition is an empirical one. Here I examine the way both issues are linked to the economic left-right dimension in the Netherlands.

Figure 1 below plots the positions of Dutch political parties on an economic left-right dimension (x-axis) and a European integration dimension (y-axis). The party positions are based on expert placements of parties using the Chapel Hill Expert Survey (CHES) trend file that asked experts to place parties on a 11 point left-right scale ranging 0) 'extreme left' to 100 extreme right as well as a 7-point European integration scale ranging from 1) 'least supportive' to 7) 'most supportive' (Bakker et al. 2015). The data was collected 
at five points in time 1999, 2002, 2006, 2010 and 2014 for 10 parties in total. ${ }^{5}$ The parties included are: 1) the conservative liberal VVD (Volkspartij voor Vrijheid en Democratie), 2) the Christian democratic CDA (Christen Democratic Appel), 3) the social democratic PvdA (Partij van de Arbeid), 4) the liberal D66 (Democraten 66), 5) the Green GL (Groen Links), 6) the socialist SP (Socialist Party), 7) the confessional CU (Christen Unie), 8) the confessional SGP (Staatskundig Gereformeerde Partij), 9) the populist PPV (Partij van de Vrijheid), and 10) the animal rights party PvdD (Partij van de Dieren).

${ }^{5}$ Experts were also asked to place parties in 1982, 1988, 1992 and 1996, yet these were mostly retrospective placements which raises some issues of measurement validity (Ray 1999). 


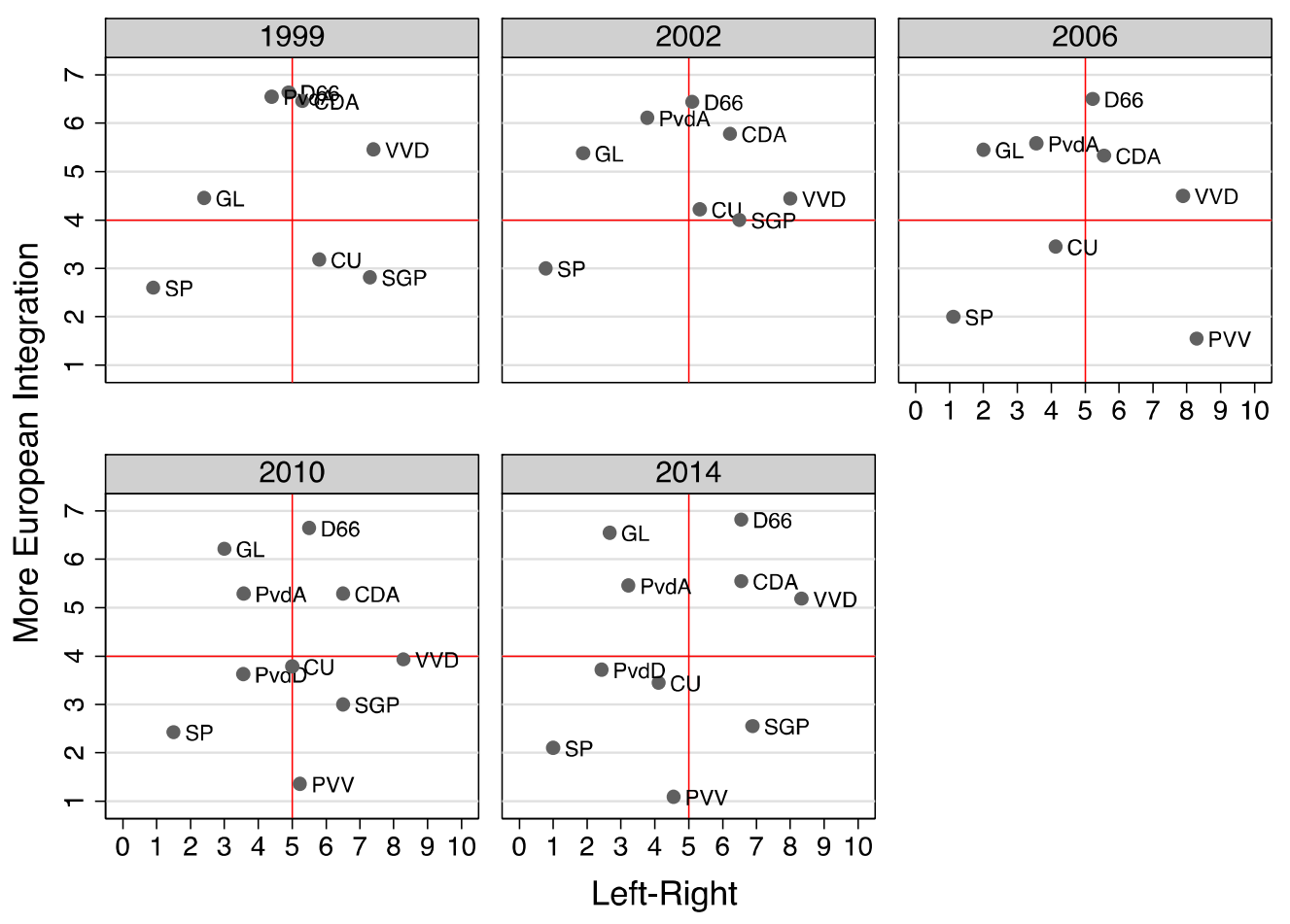

Source: Chapel Hill Expert Survey Trendfile.

Figure 1: The economic left-right and European integration positions of political parties in the Netherlands, 2006-2014

The figure suggests that while the relationship between a party's economic left-right and EU position between 1999 and 2006 somewhat resembles an inverted U-curve whereby centrist parties are most pro-EU and extremist parties most anti, this relationship starts to unravel by 2010 and 2014. In the latter period, we find that parties are pretty much evenly distributed across the four quadrants. While the positions of some parties, like the D66, $\operatorname{PvdA}$, VVD or SP, have remained quite stable over the period, others display much more change. For example, while the GL's left-right position has not changed much, the party has become more strongly pro-EU. In fact, by 2014 it is with D66 the most pro-EU party in the Dutch system. We see an opposite 
movement for the PVV. While the party has always taken a very strong antiEU position, it has moved to a more centrist, or even left of centre, position on the economic left-right dimension. Indeed, the party has aimed to defend its anti-immigrant position in part based on parochial altruism. Specifically, it wants to protect the generosity of the Dutch welfare state by denying benefits to immigrants or foreign-born citizens. When we inspect the relationship between parties economic left-right and European integration position by exploring the explained variance of a regression model that includes both parties' left-right positions and a squared term to be sensitive to the nonlinear nature of the relationship, see table 2, we find a strong co-variation between a party's left-right and European integration position until 2006. This relationship is virtually non-existent after 2010.

Table 2: Relationship between left-right and European integration position

\begin{tabular}{l|c|c|c|c|c}
\hline & $\mathbf{1 9 9 9}$ & $\mathbf{2 0 0 2}$ & $\mathbf{2 0 0 6}$ & $\mathbf{2 0 1 0}$ & $\mathbf{2 0 1 4}$ \\
\hline $\begin{array}{l}\mathrm{R}^{2} \text { including linear } \\
\text { and curvilinear } \\
\text { term }\end{array}$ & 0.48 & 0.45 & 0.52 & 0.04 & 0.07 \\
\hline $\mathrm{N}$ & 8 & 8 & 8 & 10 & 10 \\
\hline
\end{tabular}

Notes: Table entries are $\mathrm{R}^{2}$ coefficients of an ordinary regression model that includes both a party's economic left-right position and the position squared. The European integration variable ranges from 1 against more integration to 7 for more integration, and the economic left-right variable from 0 left to 10 right.

Source: Chapel Hill Expert Survey Trendfile.

What about the relationship between parties' economic left-right and immigration positions? Figure 2 presents similar information to the previous figure, namely expert placements of Dutch political parties, but this time it 
combines expert assessments of parties' economic left-right and immigration positions. Party's stances on immigration are like the left-right measured on an 11-point scale ranging from 1) 'against a restriction of immigration' to 10) 'in favour of a restriction'. Interestingly, we find a rather weak relationship between a party's position on the left-right and its position on immigration. While in 2006 there seems to be a relationship between the two, more rightwing parties are more in favour of restricting immigration, while more leftwing parties are against; by 2014 this relationship seems to have disappeared. We find parties with clear left or right positions combining them with clearly pro- or anti- immigration restriction positions. 


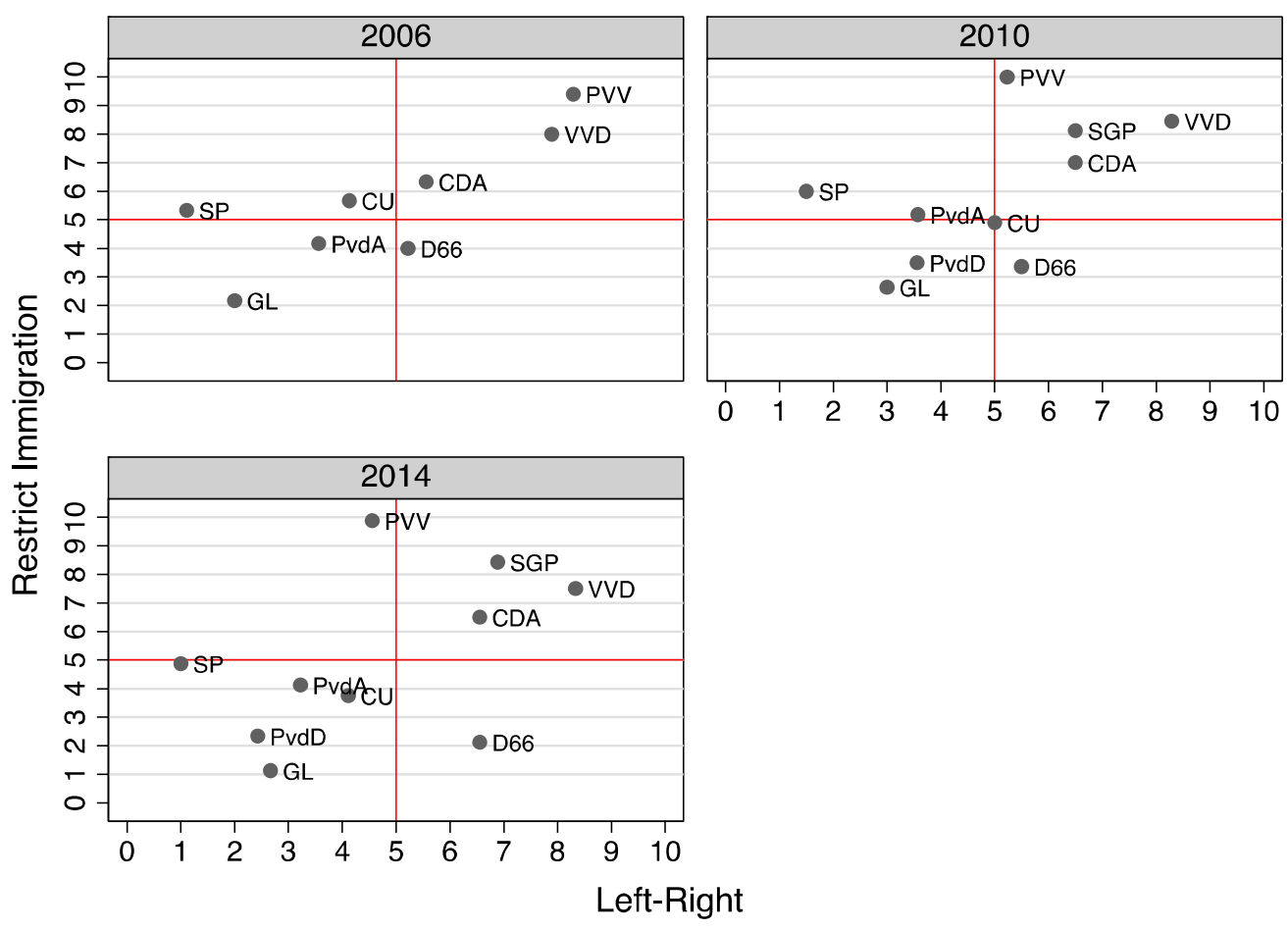

Source: Chapel Hill Expert Survey Trendfile.

Figure 2: The economic left-right and immigration positions of political parties in the Netherlands, 2006-2014

The only quadrant where parties are not strongly represented is the left and immigration restriction one. Two parties are closest to occupying this quadrant by 2014, namely the SP and PVV. While the PVV has always been in favour of restricting immigration, they have made a clear move from right to left in economic terms. The SP remains left-wing over the entire time period, but takes on a more centrist or even anti-immigration position in 2010. Part of this seems to be picking up on the somewhat difficult relationship the party has with immigration. While it is in favour of accepting refugees who face political or religious prosecution, it has ever since the publication of the report "Guest workers and Capital" in 1983, taken a sceptical position towards 
labour migration. The report was especially controversial at the time as the party suggested that foreign workers should be offered money in exchange for returning to their country of origin (SP 1983). Ever since this time, it has remained critical of labour migration. Most other left parties, perhaps with the exception of the PvdA in 2010, hold much more pro-immigration positions.

When we examine the relationship between parties' left-right and immigration positions further by means of bivariate correlations which are presented in table 3, we find that while in 2006 a party's left-right position is correlated with its immigration position (see also De Vries et al. 2013), this relationship weakens in 2010 and 2014 and is no longer statistically significant. Like in the case of parties' positioning towards European integration, party stances on immigration have become more independent of parties' left-right positions.

Table 3: Relationship between left-right and immigration position

\begin{tabular}{l|c|c|c}
\hline & 2006 & 2010 & 2014 \\
\hline Left-right & $0.80^{*}$ & 0.54 & 0.48 \\
position & $(0.02)$ & $(0.11)$ & $(0.16)$ \\
\hline $\mathrm{N}$ & 8 & 10 & 10 \\
\hline
\end{tabular}

Notes: Table entries are Pearson's R correlation coefficients with p-values in parentheses. The immigration variable ranges from 0 against a restriction of immigration to 10 in favour of a restriction of immigration, and the economic left-right variable from 0 left to 10 right.

* significant at $\mathrm{p} \leq 0.05$.

Source: Chapel Hill Expert Survey Trendfile. 
How has the relationship between party positions on European integration and immigration developed? Table 4 provides results of bivariate correlation analyses where we correlate a party's position on European integration with its immigration position. Interestingly, the results show that in 2010 and 2014 there is a significant relationship between positions on both issues. Specifically, we find that when a party becomes more in favour of restricting immigration, it coincides with a more Eurosceptic stance. So, while both European integration and immigration positions became more independent from parties' left-right positions, the positions of parties on these issues have become linked over time.

Table 4: Relationship between immigration and European integration position

\begin{tabular}{l|c|c|c}
\hline & $\mathbf{2 0 0 6}$ & $\mathbf{2 0 1 0}$ & $\mathbf{2 0 1 4}$ \\
\hline Immigration & -0.62 & $-0.69^{*}$ & $-0.62^{*}$ \\
Position & $(0.10)$ & $(0.02)$ & $(0.05)$ \\
\hline $\mathrm{N}$ & 8 & 10 & 10 \\
\hline
\end{tabular}

Notes: Table entries are Pearson's R correlation coefficients with p-values in parentheses. The European integration variable ranges from 1 against European integration to 7 in favor of European integration, immigration variable ranges from 0 against a restriction of immigration to 10 in favour of a restriction of immigration.

* significant at $\mathrm{p} \leq 0.05$.

Source: Chapel Hill Expert Survey Trendfile.

Do parties also place importance on the issues of European integration and immigration? Figure 3 shows the average level of salience a Dutch party attaches of the European integration measured between 1999 and 2014 on a 110 scale ( 1 indicating 'low salience' and 10 'high'). The figure suggests that 
there has been a slight increase in the importance parties place on the European integration issue. By 2014, the salience of European integration for an average Dutch party places is 6 points on a 10 point scale. Unfortunately, the CHES dataset only includes salience measures for immigration in two time points, 2006 and 2010, but also here the average salience is a little over 6 points on 10 points scale. This indicates that both issues by the mid-2000s are of significant importance to Dutch political parties.

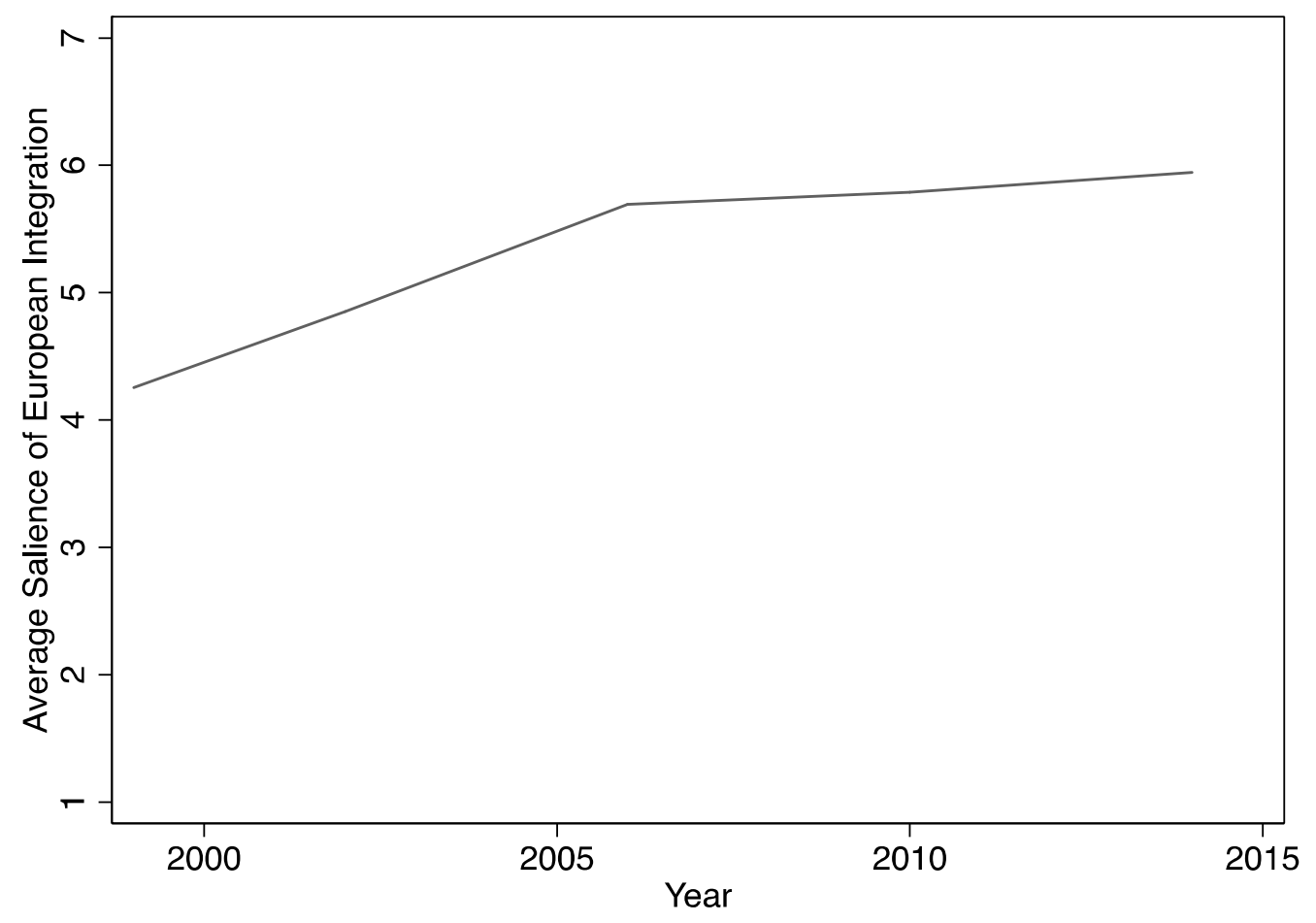

Source: Chapel Hill Expert Survey Trendfile.

Figure 3: The salience of the European Integration Issue Averaged across Dutch political parties, 1999-2014

The results thus far suggest that party positioning on the issues of European integration and immigration in the Netherlands has become linked over time and at the same time more distinct from party positioning on the economic 
left-right. Moreover, parties attach great importance to both issues. All in all, it seems to suggest that by 2014, Dutch party competition is characterized by a second dimension relating to the country's openness to foreigners and foreign influence. I coin this second dimension the cosmopolitan-parochial divide as it pits cosmopolitan parties on the left and right, like the GL or D66, that advocate an inclusionary and international outlook against parochial parties on the left and right that are increasingly wary of open borders and international political influence, such as the SP or the PVV. Merton (1968) describes a cosmopolitan attitude as a more open, global orientation displaying a higher interest in, and awareness of, distant events. This is opposed to a more local or parochial attitude that is more inward looking (see also Vertovec and Cohen 2002).

How does this cosmopolitan-parochial divide differ from other existing conceptualizations in the literature? Kriesi and his colleagues (2006, 2008) for example refer to a similar set of issues as the integrationdemarcation dimension, while Hooghe and Marks (2017) denote it the transnational cleavage. My approach differs from these existing perspectives in important ways. Hooghe and Marks view the transnational cleavage as the new vocal point of party competition, while Kriesi and colleagues suggest that issues relating to economic and cultural globalization have redefined the content of the economic and non-economic dimensions. Both sets of authors stress that socio-structural change, critical junctures and public demand have 
shifted the main axis of competition and changed the content of political competition on both dimensions. What I argue here is that political space in the Netherlands is increasingly two-dimensional in nature, and that these two dimensions have become largely orthogonal from each other. While one dimension relates to issues of redistribution, state intervention in the economy and (re-) allocation of resources, the other refers to questions of who belongs to the polity and how much influence outside actors, like supranational organizations, should have on law-making. These two dimensions are what Kitschelt and Rehm (2015) refer to as the 'group' and 'greed' dimension. ${ }^{6} \mathrm{I}$ am not necessarily arguing that we are witnessing political change based on the fact that transnational or globalization issues that have come to redefine the main axis of competition or both the economic and non-economic dimension, but rather that the two dimensions have become cross-cutting. The significance of the classical economic left-right dimension in party and electoral competition remains strong and centers on much the same issues as in the past. What we are seeing is not a shift in the main dimension of competition, but rather the development of four distinct blocks of competition, namely the cosmopolitan-left, the cosmopolitan-right, the parochial-left and the parochial-right.

${ }^{6}$ The third grid dimension that the authors outline, relates to moral topics does not strongly come to the fore in Dutch politics in 2014, see Table 5 especially. This dimension may only play a role for the small Christian parties like the CU or SGP. 
I develop an empirical measure of parties' cosmopolitan versus parochial stances by combining their positions on European integration and immigration. ${ }^{7}$ Figure 4 below plots parties' cosmopolitan versus parochial stances against their economic left-right stances. While only the SP, SGP and PVV consistently fall in the left-parochial or right-parochial quadrants, parties like the CU or VVD do in 2006, but move to more centrist positions in 2010 and 2014. The clearest examples of left-cosmopolitan and right-cosmopolitan parties are the GL and D66 respectively. The 2017 election result that showed significant gains for the most parochial party (PVV) and most cosmopolitan ones (GL and D66) fits these patterns of change. Now we turn to the question if the cosmopolitan-parochial divide also characterizes voters' positions and their behaviour in elections.

${ }^{7}$ I transform the European integration scale from a 7 to 11-point scale where higher values mean more sceptical positions, and subsequently create an additive scale that I divide by 2 . 


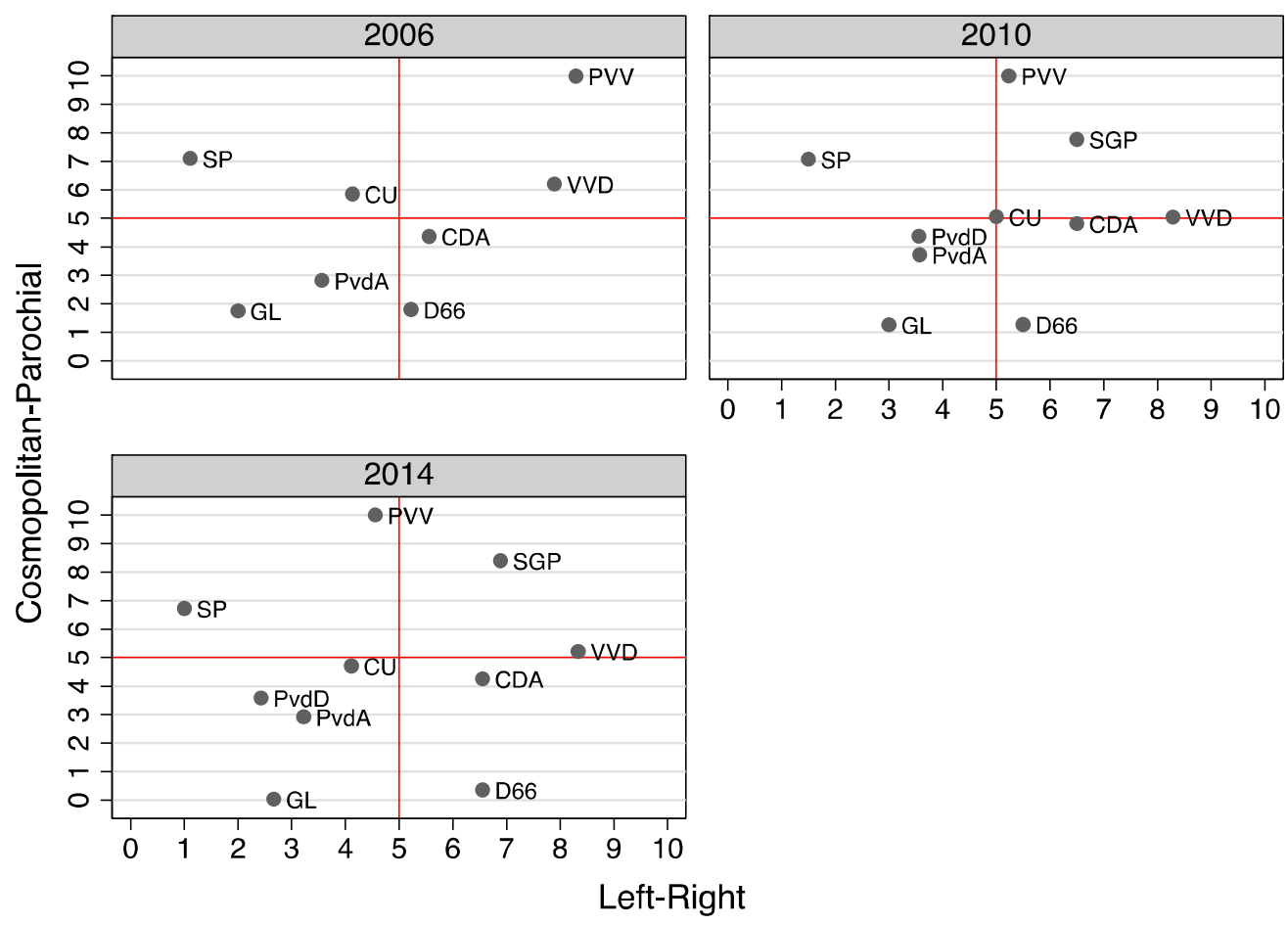

Source: Chapel Hill Expert Survey Trendfile.

Figure 4: Party positions on the economic left-right and cosmopolitanparochial divide, 2006-2014

\section{The Cosmopolitan-Parochial Divide and Voter Decision-Making}

In order to explore if Dutch voters' issue positions resemble those of parties, we explore the dimensionality of people's stances on a number of issues. We do so by using a battery of issue positions questions that was included in the most recent round of the European Election Study (EES) from 2014 (Schmitt et al. 2016). The questions tapping into people's left-right, European integration and immigration positions are identical in wording to those included in the CHES data that I relied on in the previous section. It also includes more questions concerning people's stances on redistribution, same-sex marriage, 
privacy protection and climate change. All items were measured on an 11point scale and coded in such a way that higher values reflect more right and conservative positions. To explore the potential dimensionality underlying these issues, I performed a Mokken scaling analysis and the results are presented in table 5 below (Van Schuur 2003).

Table 5: Dimensionality of voters' positions

\begin{tabular}{l|c|c}
\hline & $\begin{array}{c}\text { Scale 1 } \\
\text { H-coefficients }\end{array}$ & $\begin{array}{c}\text { Scale 2 } \\
\text { H-coefficients }\end{array}$ \\
\hline Left-right position & 0.42 & \\
\hline $\begin{array}{l}\text { Anti-redistribution } \\
\text { position }\end{array}$ & 0.42 & 0.45 \\
\hline $\begin{array}{l}\text { Anti-European } \\
\text { integration position }\end{array}$ & & 0.42 \\
\hline $\begin{array}{l}\text { National control } \\
\text { position }\end{array}$ & & 0.34 \\
\hline $\begin{array}{l}\text { Anti-immigration } \\
\text { position }\end{array}$ & & 0.34 \\
\hline Scale H-coefficient & 0.42 & 1065 \\
\hline
\end{tabular}

Notes: The standard criteria was used to form a scale, namely $H_{i k}>$.3. People's positions on privacy, same-sex marriage and climate change did not meet the criterion to form a scale or be included in one.

Source: European Election Study 2014.

The results from the Mokken scaling analysis suggest that two dimensions emerge from the data, one economic left-right dimension tapping into people's left-right and redistribution positions as well as a cosmopolitanparochial dimension reflecting people's stances on European integration, national control in international politics and immigration. These dimensions are only weakly related, the Pearson's R correlation coefficient is $0.2(p=.00)$. 
These findings are in line with recent scholarship on public opinion towards economic globalization in Europe and beyond that suggests that popular opposition is motivated by cosmopolitanism and other-regarding preferences (Margalit 2012, Bechtel et al. 2014, Kuhn et al. 2017) or support for foreign aid is driven by paternalistic considerations and prejudices (Baker 2015).

Interestingly, items tapping people's views about privacy, same-sex marriage and climate change do not load onto the second dimension or form a separate dimension themselves. This finding runs counter recent crossnational work suggesting that the second dimension is largely cultural in nature (most notably Inglehart and Norris 2011, 2016). For Dutch voters this does not necessarily seem to be the case. Cultural liberal stances about samesex marriage for example are not part of the cosmopolitan-parochial divide.

How much do people's stances on the cosmopolitan-parochial divide affect their vote choice? In order for people's stances on the cosmopolitanparochial divide to matter, people need to care about these issues vis-á-vis economic left-right issues, and they need to find these issues important enough to influence their behaviour at the ballot box (De Vries 2007, 2018). I examine this in two steps. First, I explore the salience people attach to issues relating to the economic left-right and cosmopolitan-parochial divide, and second, I explore how people's positions on these dimensions affect their vote for parties in national and European parliamentary elections. Figure 5 presents an overview of the importance supporters of different Dutch political 
parties attach to issues relating to the economic left-right dimension, unemployment and pensions, and those relating to the cosmopolitanparochial dimension, powers of EU institutions, the Euro and immigration. These responses are based on questions asking people what the most important problems are that face the Netherlands today. The figure includes supporters of all parties that were discussed in the previous section as well as the pensioners' party 50Plus.

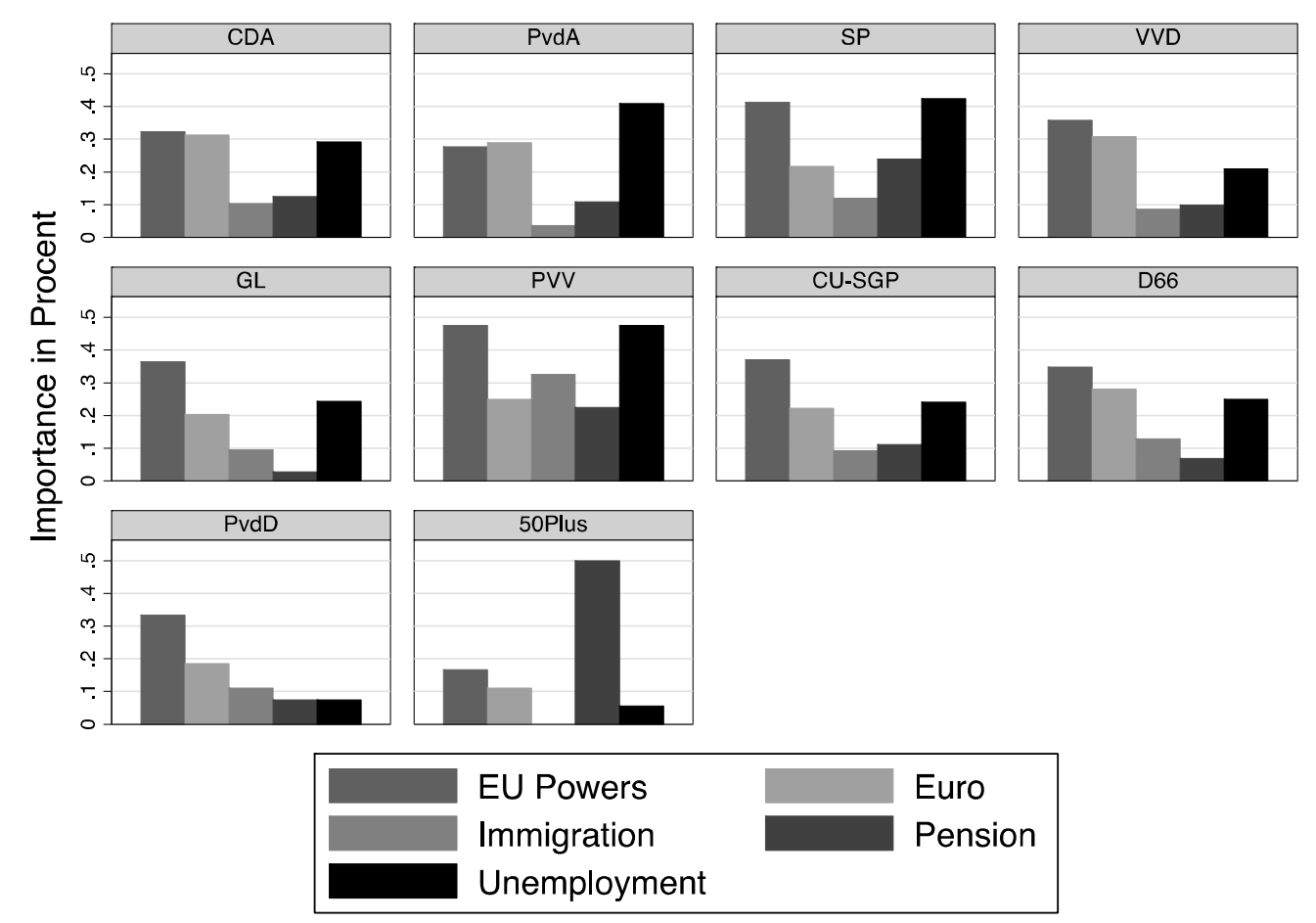

Source: European Election Study 2014.

Figure 5: Importance of economic left-right and cosmopolitan-parochial issues among Dutch voters

The results show that both sets of issues are important, but that for Dutch voters EU powers and unemployment were the most important. The only 
exception here is the voters of the 50Plus party for whom pensions was the most important issue. Although one needs to be sensitive to the fact that the survey was conducted in the context of the 2014 EP elections so the importance of EU issues might be somewhat inflated, issues relating to European integration have clearly gained in importance in Dutch politics in recent years given in response to the Eurozone crisis and Brexit decision in the United Kingdom (De Vries 2017, 2018).

Another way to examine if voters view their stances on the cosmopolitan-parochial dimension as important is by examining the extent to which they impact people's decision making at the ballot box. Tables 6A and $6 \mathrm{~B}$ present results from multinomial logistic regression analyses of people's recall of their vote choices in the 2014 EP election (EP vote) and the 2012 national parliamentary elections (NP vote). In order to capture the effect of people's stances on the economic left-right and cosmopolitan-parochial dimensions, I use the items that scaled together on both dimensions as shown in table 5 , and added and divided them by the number of items included 1 to form one scale ranging from 0 left/cosmopolitan and 10 right/parochial respectively. Party choice for the biggest incumbent party, the VVD, serves as the reference category in the analysis and all models include the following individual level covariates which are not shown here: government approval, retrospective economic evaluations, age, gender, education, unemployed, working class self identification, self employed, professional worker and 
trade union membership. This analysis is able to point at correlations between stated party choice and issue positions, but issues of causality remain. That is to say do people vote for certain parties due to their issue preferences or the reverse?.

Table 6A: Relationship between people's economic left-right and cosmopolitan-parochial positions and vote choice in 2014 European Parliament election

\begin{tabular}{|c|c|c|c|c|c|c|c|}
\hline EP vote & CDA & PvdA & SP & GL & PVV & CU/SGP & D66 \\
\hline $\begin{array}{l}\text { Economic Left- } \\
\text { Right }\end{array}$ & $\begin{array}{r}-0.62^{*} \\
(0.12)\end{array}$ & $\begin{array}{r}-1.48^{*} \\
(0.15)\end{array}$ & $\begin{array}{l}-1.77^{*} \\
(0.15)\end{array}$ & $\begin{array}{l}-1.62^{*} \\
(0.16)\end{array}$ & $\begin{array}{l}-0.73^{*} \\
(0.15)\end{array}$ & $\begin{array}{l}-0.62^{*} \\
(0.14)\end{array}$ & $\begin{array}{l}-0.80^{*} \\
(0.12)\end{array}$ \\
\hline $\begin{array}{l}\text { Cosmopolitanism- } \\
\text { Parochial }\end{array}$ & $\begin{array}{c}0.07 \\
(0.10)\end{array}$ & $\begin{array}{l}-0.19 \\
(0.12) \\
\end{array}$ & $\begin{array}{l}0.35^{*} \\
(0.12)\end{array}$ & $\begin{array}{l}-0.36^{*} \\
(0.13)\end{array}$ & $\begin{array}{l}0.74^{*} \\
(0.14)\end{array}$ & $\begin{array}{c}0.16 \\
(0.12) \\
\end{array}$ & $\begin{array}{l}-0.28^{*} \\
(0.10)\end{array}$ \\
\hline $\begin{array}{l}\text { Individual Level } \\
\text { Covariates }\end{array}$ & $\checkmark$ & $\checkmark$ & $\checkmark$ & $\checkmark$ & $\checkmark$ & $\checkmark$ & $\checkmark$ \\
\hline EP vote & PvdD & 50Plus & & & & & \\
\hline $\begin{array}{l}\text { Economic Left- } \\
\text { Right }\end{array}$ & $\begin{array}{l}-1.51^{*} \\
(0.19) \\
\end{array}$ & $\begin{array}{l}-0.98^{*} \\
(0.19) \\
\end{array}$ & & & & & \\
\hline $\begin{array}{l}\text { Cosmopolitanism- } \\
\text { Nationalism }\end{array}$ & $\begin{array}{l}0.38^{*} \\
(0.15)\end{array}$ & $\begin{array}{c}0.27 \\
(0.17)\end{array}$ & & & & & \\
\hline $\begin{array}{l}\text { Individual Level } \\
\text { Covariates }\end{array}$ & $\checkmark$ & $\checkmark$ & & & & & \\
\hline LR Chi² & \multicolumn{2}{|c|}{$742.93^{*}$} & & & & & \\
\hline Pseudo R ${ }^{2}$ & \multicolumn{2}{|c|}{0.24} & & & & & \\
\hline $\mathrm{N}$ & \multicolumn{2}{|c|}{686} & & & & & \\
\hline
\end{tabular}

Notes: Table entries are multinomial regression coefficients with standard errors in parentheses. ${ }^{*}$ significant at the $\mathrm{p}<.05$. Vote for the VVD is the reference category. The following individual level covariates were included: government approval, retrospective economic evaluations, age, gender, education, unemployed, working class self identification, self employed, professional worker and trade union membership.

Source: European Election Study 2014. 
Table 6B: Relationship between people's economic left-right and cosmopolitan-parochial positions and vote choice in previous national election

\begin{tabular}{|c|c|c|c|c|c|c|c|}
\hline NP vote & CDA & PvdA & SP & GL & PVV & $\mathrm{CU}$ & D66 \\
\hline $\begin{array}{l}\text { Economic Left- } \\
\text { Right }\end{array}$ & $\begin{array}{l}-0.33^{*} \\
(0.10)\end{array}$ & $\begin{array}{l}-1.27^{*} \\
(0.10)\end{array}$ & $\begin{array}{l}-1.56^{*} \\
(0.12)\end{array}$ & $\begin{array}{l}-1.41^{*} \\
(0.13)\end{array}$ & $\begin{array}{l}-0.75^{*} \\
(0.12)\end{array}$ & $\begin{array}{l}-0.64^{*} \\
(0.13)\end{array}$ & $\begin{array}{l}-0.65^{*} \\
(0.09)\end{array}$ \\
\hline $\begin{array}{l}\text { Cosmopolitan- } \\
\text { Parochial }\end{array}$ & $\begin{array}{l}-0.10 \\
(0.08)\end{array}$ & $\begin{array}{l}-0.26^{*} \\
(0.08)\end{array}$ & $\begin{array}{c}0.09 \\
(0.09)\end{array}$ & $\begin{array}{l}-0.30^{*} \\
(0.11)\end{array}$ & $\begin{array}{l}0.40^{*} \\
(0.10)\end{array}$ & $\begin{array}{c}-0.12 \\
(0.11)\end{array}$ & $\begin{array}{l}-0.27^{*} \\
(0.07)\end{array}$ \\
\hline $\begin{array}{l}\text { Individual Level } \\
\text { Covariates }\end{array}$ & $\checkmark$ & $\checkmark$ & $\checkmark$ & $\checkmark$ & $\checkmark$ & $\checkmark$ & $\checkmark$ \\
\hline NP vote & PvdD & 50Plus & SGP & & & & \\
\hline $\begin{array}{l}\text { Economic Left- } \\
\text { Right }\end{array}$ & $\begin{array}{l}-1.05^{*} \\
(0.19) \\
\end{array}$ & $\begin{array}{l}-1.05^{*} \\
(0.21) \\
\end{array}$ & $\begin{array}{l}-0.21 \\
(0.17)\end{array}$ & & & & \\
\hline $\begin{array}{l}\text { Cosmopolitan- } \\
\text { Parochial }\end{array}$ & $\begin{array}{c}0.16 \\
(0.16)\end{array}$ & $\begin{array}{c}0.27 \\
(0.20)\end{array}$ & $\begin{array}{c}0.16 \\
(0.14)\end{array}$ & & & & \\
\hline $\begin{array}{l}\text { Individual Level } \\
\text { Covariates }\end{array}$ & $\checkmark$ & $\checkmark$ & $\checkmark$ & & & & \\
\hline LR Chi ${ }^{2}$ & \multicolumn{3}{|c|}{857.63} & & & & \\
\hline Pseudo R ${ }^{2}$ & \multirow{2}{*}{\multicolumn{3}{|c|}{$\begin{array}{l}0.22 \\
912\end{array}$}} & & & & \\
\hline $\mathrm{N}$ & & & & & & & \\
\hline
\end{tabular}

Notes: Table entries are multinomial regression coefficients with standard errors in parentheses. * significant at the $\mathrm{p}<.05$. Vote for the VVD is the reference category. The following individual level covariates were included: government approval, retrospective economic evaluations, age, gender, education, unemployed, working class self identification, self employed, professional worker and trade union membership.

Source: European Election Study 2014.

The results suggest that people's cosmopolitan-parochial positions indeed matter for both vote choice in EP and national elections. People's stances on the cosmopolitan-parochial divide are especially important for those stating that they voted for the GL or D66 versus the VVD or the PVV versus the VVD. These findings dovetail with some of the findings documented for parties in the previous sections, as the GL and D66 versus the PVV constitute the poles of the cosmopolitan-parochial divide. Does the inclusion of people's cosmopolitan-parochial positions improve the model of vote choice? I test this 
by relying on a likelihood-ratio test that examines if the full model, the one that includes cosmopolitan-parochial positions, is an improvement of a restricted model that only includes left-right placements and individual level controls. The likelihood-ratio tests suggests that both for EP and NP vote the inclusion of voter's positions on the second dimension significantly improves the model, but the improvement is bigger for vote choice in EP elections (LR test $($ EPVote $)=123.11, \mathrm{p}=.00 /$ LR test $($ NPvote $)=88.11, \mathrm{p}=.00)$.

Overall, this evidence suggests that the dimensionality of Dutch voters' issue positions closely mimics those of parties. Two dimensions are crucial for understanding how the average Dutch voter views the political world and decides which party to support, the economic left-right and cosmopolitanparochial dimensions. Both of these dimensions matter to voters in how they position themselves politically. Interestingly, we find that in the Netherlands people's views about gay and lesbian rights or the environment are not linked to the second dimension. This finding perhaps reflects the fact that parties like the PVV for example champion their anti-immigration and anti-Islam positions as a defence of Dutch liberal values of tolerance towards gays and lesbians as well as women's rights. ${ }^{8}$ This Dutch evidence goes counter some recent work suggesting that the recent rise of populism constitutes largely a popular backlash against cultural liberalism (Inglehart and Norris 2016). This

\footnotetext{
${ }^{8}$ See also http://www.elsevier.nl/nederland/achtergrond/2017/03/kandidaatpartij-simons-wilders-gebruikt-homos-als-wapen-463254/.
} 
may be the case for recent developments in the United States or Poland for example, but does not generalize to some countries in Western Europe, like the Netherlands. This context-specificity of the second dimension is an important topic for future research.

In a final step, I examine the nature of people's stances on the cosmopolitan-parochial divide further by exploring an alternative explanation for what drives people's views on this divide, namely economic uncertainty. This perspective does not so much understand the development of a cosmopolitan-parochial divide as a cultural backlash against liberalism, such as the extension of women's rights or protection of gay and lesbian or ethnic minority rights, but stresses more the economic nature of it. Increasing transnational political and economic cooperation has made a large segment of the population feel more economically insecure (Hacker 2006, Hacker et al. 2013). As a result, people feel left behind by globalization and that political elites no longer look out for them. People support political outsiders who skilfully articulate their fears about globalization linked to their economic situation and skill competition by immigrants. In his book the Globalization Paradox, Dani Rodrik (2011) for example argues globalization presents a trilemma as societies cannot be globally integrated, completely sovereign and democratic at the same time. Using this type of reasoning, deeper economic integration accompanied by further political integration in Europe would likely lead to resistance amongst the most vulnerable demanding a fair 
distribution of wealth and jobs, an increase in trade protectionism and for their government to take back control. International market integration favours citizens with higher levels of human capital, such as education and occupational skills, and income (Gabel 1998, Scheve and Slaughter 2001, Fordham 2008). The Brexit vote in the United Kingdom has been attributed to a revolt of those left behind by globalization for example (Goodwin and Heath 2016, Hobolt 2016, Clarke et al. 2017).

I examine the economic insecurity explanation in the Dutch context by exploring if those who were hardest hit in the Eurozone crisis also display a higher level of parochialism and a greater likelihood to support parochial parties in the Dutch political landscape, like the PVV or SP. The crisis could have influenced citizens in many different ways, but most significant was a loss of employment in the household and/or a significant reduction in household income. Of course, those who experience such loss are not a randomly drawn from the population. They mostly already find themselves in a precarious economic position. In order to control for this, the analysis relies on a matching technique. This is a means by which to isolate the effect of being adversely affected by the crisis by matching respondents on a whole set of demographic variables. We employ the nearest-neighbour matching (NN matching) as an optimization method for finding the closest (or most similar) individuals. Closeness is expressed in terms of a dissimilarity function: the less similar the individuals, the larger the function values (Rubin 
1973). It selects for each treated individual the control individual with the smallest distance from the treated individual. By using NN matching we are able to estimate the effect of being adversely affected by the crisis by accounting for the covariates that predict the likelihood of being affected like employment status, level of education, age, occupational skills and gender.

The 2014 EES survey includes a question asking people if they experienced a loss in employment or reduction in household during the last 24 months. In order to examine if people who were adversely affected by the crisis are more likely to hold parochial attitudes, we create a variable that takes on a value of 1 when people experienced a job loss or reduction in household income and 0 if they did not. We examine the effect of being adversely affected by the crisis on two outcome variables: a) people's cosmopolitan-parochial positions ranging from 0) 'cosmopolitan' to 10) 'parochial', and b) vote for parochial parties in the last national election coded as 1) if a person voted for the PVV, SP or SGP in the last national election, and 0) for another party. 
Table 7: The effect of economic loss on cosmopolitan-parochial positions and vote for parochial parties

\begin{tabular}{l|c|c}
\hline & $\begin{array}{c}\text { Cosmopolitan- } \\
\text { Parochial Positions }\end{array}$ & $\begin{array}{c}\text { Vote for Parochial } \\
\text { Parties }\end{array}$ \\
\hline Adversely Affected by & $0.28^{*}$ & $0.06^{*}$ \\
Crisis & $(0.16)$ & $(0.03)$ \\
\hline Matched on Individual & $\checkmark$ & $\checkmark$ \\
Level Covariates & 1070 & 1001 \\
\hline $\mathrm{N}$ & & \\
\hline
\end{tabular}

Notes: Table entries are OLS regression coefficients from based on a NN-matching procedure with standard errors in parentheses. The dependent variable in the second column ranges from 0 cosmopolitan to 10 parochial, and in the third column from 1 vote for parochial party (PVV, SP or SGP) in the previous national election, 0 vote for other party. ${ }^{*}$ significant at $\mathrm{p} \leq 0.05$.

Source: European Election Study 2014.

Table 7 presents the results. The results indicate that being adversely affected by the crisis makes Dutch voters more parochial, a quarter of a point on a 11point scale. Moreover, being affected by the crisis increases the likelihood of a Dutch voter voting for a parochial party. These results seem to suggest that among Dutch voters economic loss is a big driver of scepticism towards immigration, European integration or international cooperation more broadly. This evidence suggests that we ought to be careful to depict recent rise in parochialism as motivated predominantly by cultural fears (see also Rae Berg et al. 2017).

In fact, when we examine the individual level characteristics of those who are more parochial versus more cosmopolitan more in-depth, here presented in table 8, two factors stand out: education and the degree to which people worry about having enough money at the end of the month. 
Interestingly, people's level of national attachment does not correlate with people's stances on the cosmopolitan-parochial dimension. It is the lower educated and financially worried who are more likely to display parochial views compared to those with higher education and less financial worries. 
Table 8: Correlates of cosmopolitan-parochial positions

\begin{tabular}{|c|c|}
\hline & $\begin{array}{c}\text { Parochial-Cosmopolitan } \\
\text { Positions }\end{array}$ \\
\hline Education & $\begin{array}{l}-0.74^{*} \\
(0.10)\end{array}$ \\
\hline Financial worry & $\begin{array}{l}0.25^{*} \\
(0.11)\end{array}$ \\
\hline National attachment & $\begin{array}{l}-0.11 \\
(0.12)\end{array}$ \\
\hline Age & $\begin{array}{l}-0.01 \\
(0.00)\end{array}$ \\
\hline Gender & $\begin{array}{c}0.08 \\
(0.01)\end{array}$ \\
\hline $\begin{array}{l}\text { Working class } \\
\text { identification }\end{array}$ & $\begin{array}{c}0.26 \\
(0.39) \\
\end{array}$ \\
\hline Employed & $\begin{array}{c}0.08 \\
(0.26) \\
\end{array}$ \\
\hline Professional worker & $\begin{array}{l}-0.11 \\
(0.21)\end{array}$ \\
\hline Self-employed & $\begin{array}{l}-0.14 \\
(0.41)\end{array}$ \\
\hline Urban residence & $\begin{array}{l}-0.08 \\
(0.08)\end{array}$ \\
\hline $\begin{array}{l}\text { Trade union } \\
\text { membership }\end{array}$ & $\begin{array}{l}0.09 \\
0.13\end{array}$ \\
\hline Constant & $\begin{array}{l}8.43^{*} \\
(0.64)\end{array}$ \\
\hline $\mathrm{R}^{2}$ & 0.07 \\
\hline $\mathrm{N}$ & 1070 \\
\hline
\end{tabular}

Notes: Table entries are OLS regression coefficients with standard errors in parentheses. The dependent variable ranges from 0 cosmopolitan to 10 parochial. * significant at $\mathrm{p} \leq 0.05$. Source: European Election Study 2014.

Notwithstanding the fact that we need to be careful about these types of correlations as it might be the case that wealthier voters may experience greater social pressures to appear less prejudiced and more cosmopolitan as a consequence of social desirability bias in answering surveys (An 2015), these 
results together with the ones presented in table 7 suggest that in the Netherlands people's cosmopolitan-parochial views might be driven more by economic insecurities than a backlash against cultural liberalism. This is further supported by earlier findings reported here that suggested that people's opinions about culturally liberal issues such as same-sex marriage, privacy or climate change are largely unrelated to people's stances on the cosmopolitan-parochial divide. In the Netherlands, the cosmopolitanparochial divide might be more the result of people fearing and experiences negative side effects of international political and economic cooperation.

\section{Conclusion}

The Brexit vote, the election of Donald Trump, and the electoral success of populist forces across the globe seem indicative of a backlash against economic and political cooperation across borders. The 2017 election outcome in the Netherlands also saw gains for the party of the anti-Islam and anti-EU political entrepreneur, Geert Wilders. Yet, his Party for Freedom did not do as well as the polls had initially indicated, and more progressive and pro-EU forces, mostly notably the Greens, made enormous electoral strides. What does this result tell us about patterns of party and electoral competition in the Netherlands and perhaps in Europe more broadly? 
This article uncovers important trends in political competition in the Netherlands over the past two decades and aims to place them in a larger context of the rise of so-called populist forces. It highlights three specific trends in Dutch politics. First, questions of migration, European integration and international cooperation, next to economic left-right issues, have become more central to party and voter polarization. Second, party and polarization over these issues has more distinct from polarization on the economic leftright, and resembles a cosmopolitan-parochial divide pitting parties and voters with a more inclusionary and international outlook on both the left and right, against parochial parties and voters on both the left and right that that aim to tame international influences and are increasingly suspicious of open borders. Positions on cosmopolitanism-parochial divide now structure people's party choice in both European and national parliamentary elections in the Netherlands, especially for parties that are clearly parochial (like the party of Wilders) or clearly cosmopolitan (like the Greens). That said, for most Dutch voters the economic left-right remains the key focal point. Third and finally, this second dimension in Dutch politics seems less the result of a popular backlash against cultural liberalism, but more a consequence of economic insecurity.

This study highlights that Dutch political parties often described as populist, the Socialist Party and Party for Freedom, display similarities in that they are both vocal opponents of cosmopolitanism. Interestingly, by 2014 
Geert Wilders' party is economically more on the left and right, hence resembling the issue positions of the Socialist party even more. Indeed, the Party for Freedom clashed with the minority government it supported from parliament between 2010 and 2012 over cuts in social benefits. ${ }^{9}$ The opposite pole on the cosmopolitan-parochial divide is inhabited by the Green Left and Liberal Democats (D66). These parties increasingly differentiate themselves from their mainstream left and right competitors, like the Labour Party (PvdA) or Conservative Liberals (VVD), based on their pro-immigration and pro-EU stances.

The growing importance of cosmopolitan-parochial divide in Dutch politics seems to reflect people's views about how to cope in an increasingly globalized world (see also Kriesi et al. 2008). The analysis uncovers that positions of voters on the cosmopolitan-parochial divide are not so much related to their views on same-sex marriage or the environment, but reflect their experiences in the recent Eurozone crisis. Those who were hardest hit turned to parochial parties, on the left or right, and displayed less cosmopolitan positions compared to those who were not affected.

Given that the cosmopolitan-parochial divide is largely unrelated to economic left-right, we have witnessed parties traditionally associated with the extreme left and right in Dutch politics, the Socialist Party and Party for

\footnotetext{
${ }_{9}$ See https://www.npofocus.nl/artikel/7493/waarom-mislukte-regeren-metpvv-steun (accessed 24th of April 2017).
} 
Freedom respectively, now representing and catering towards very similar clienteles. This does not seem to be an entirely Dutch phenomenon. There are clear similarities between the parochial stances of the Left Party and Alternative for Germany in Germany, or French presidential candidates Le Pen and Melenchon. Although the parochial left and right parties/candidates differ on many respects, they share scepticism towards the policy direction of the EU and/or labour migration. It is an important area of future research to aim to delve deeper into understanding the shared rhetoric of parochial left and right parties. A recent study by Mudde and Kaltwasser (2013) constitutes an important starting point.

Yet, there are surely limits to how much we can generalize from these Dutch results. While in the Netherlands opposition to cultural liberalism is not the core of the cosmopolitan-parochial divide, in other European countries cultural issues might be more important. Here, we can think of countries like Poland for example. Moreover, Dutch politics is characterized by an extremely low electoral threshold that allows for the parliamentary representation of many parties. Arguably, this is a very favourable context for the development of a largely orthogonal second dimension where different types of parties, left-parochial, right-parochial, left-cosmopolitan and rightcosmopolitan, emerge. In countries where electoral rules are less permissive, like the United Kingdom for example, and not many parties are represented in parliament, voters will need to make important trade-offs at election time. 
They will need to decide how much they care about their economic left-right positions versus their cosmopolitan-parochial ones. As a result, rifts are likely to characterize both parties as well as their core supporters. This might be exactly what we are witnessing in post-Brexit Britain.

Finally, the content of the second dimension may crucially dependent on the strategic choices of political entrepreneurs, both within existing parties and in new ones (Hobolt and De Vries 2015). They can try to contain the potentially disruptive force of people's cosmopolitan or parochial concerns by linking them closely to their economic left-right positioning, or they can try to distinguish themselves from mainstream competitors by carving out the differences with economic positions. Future elections in Europe are likely to be shaped by these centrifugal and centripetal forces.

\section{Disclosure statement}

No potential of interest was reported by the author.

\section{Notes of contributors}

Catherine E. De Vries is a Professor of Politics at the University of Essex. 


\section{References}

An, B. P. 2015. The role of social desirability bias and racial/ethnic composition on the relation between education and attitude toward immigration restrictionism. The Social Science Journal 52 (4), 459 - 467.

Baker, A. (2015). Race, Paternalism, and Foreign Aid: Evidence from U.S. Public Opinion. American Political Science Review, 109(1), 93-109.

Bakker, R., De Vries, C., Edwards, E., Hooghe, L., Jolly, S., Marks, G., Polk, J., Rovny, J., Steenbergen, M. \& Vachudova, M. A. (2015). Measuring party positions in Europe: The Chapel Hill expert survey trend file, 1999-2010. Party Politics, 21(1), 143-152.

Bechtel, M., Hainmueller, J., \& Margalit, Y. (2014). Preferences for International Redistribution. The Divide over the Eurozone Bailouts. American Journal of Political Science, 58(4), 835-856.

Clarke, H., Goodwin, M. \& Whiteley, P. (2017). Brexit! Why Britain Voted to Leave the European Union. Cambridge University Press.

Dalton, R. J. (2002). Citizen Politics: Public Opinion and Political Parties in Advanced Western Democracies. Chatham.

De Vries, C. E. (2018). Euroscepticism and the Future of European Integration. Forthcoming with Oxford University Press.

De Vries, C. E. (2017) Benchmarking Brexit: How the British Decision to Leave Shapes EU Public Opinion. JCMS: The Journal of Common Market Studies, 55(S1).

De Vries, C. E. (2007). Sleeping giant: Fact or fairytale? How European integration affects national elections. European Union Politics, 8(3), 363-385.

De Vries, C. E., \& Edwards, E. E. (2009). Taking Europe to its extremes extremist parties and public Euroscepticism. Party Politics, 15(1), 5-28.

De Vries, C. E., \& Marks, G. (2012). The struggle over dimensionality: A note on theory and empirics. European Union Politics 15(1), 185-193.

De Vries, C. E., Hakhverdian, A., \& Lancee, B. (2013). The dynamics of voters' left/right identification: The role of economic and cultural attitudes. Political Science Research and Methods, 1(2), 223-238. 
Inglehart, R. (1990). Culture shift in advanced industrial society. Princeton University Press.

Norris, P., \& Inglehart, R. (2011). Sacred and secular: Religion and politics worldwide. Cambridge University Press.

Inglehart, R. and Norris, P. (2016). Trump, Brexit, and the Rise of Populism: Economic Have-Nots and Cultural Backlash. Faculty Research Working Paper Series (RWP16-026).

Fordham, B. O. (2008). Economic Interests and Public Support for American Global Activism. International Organization 62(1), 168-182.

Gabel, M. J. (1998). Interests and integration: Market liberalization, public opinion, and European Union. University of Michigan Press.

Gabel, M. J., \& Anderson, C. J. (2002). The structure of citizen attitudes and the European political space. Comparative Political Studies, 35(8), 893-913.

Goodwin, M. J., \& Heath, O. (2016). The 2016 Referendum, Brexit and the Left Behind: An Aggregate-level Analysis of the Result. Political Quarterly, 87(3), 323-332.

Hacker, J. S. (2006). The great risk shift: The new economic insecurity and the decline of the American dream. Oxford University Press.

Hacker, J. S., Rehm, P., \& Schlesinger, M. (2013). The insecure American: Economic experiences, financial worries, and policy attitudes. Perspectives on Politics, 11(01), 23-49.

Hix, S., \& Lord, C. (1997). Political parties in the European Union. New York: St. Martin's Press.

Hobolt, S. B. (2016). The Brexit vote: a divided nation, a divided continent. Journal of European Public Policy, 23(9), 1259-1277.

Hobolt, S. B., \& De Vries, C. E. (2015). Issue entrepreneurship and multiparty competition. Comparative Political Studies, 48(9), 1159-1185.

Hobolt, S. B., \& De Vries, C. (2016). Turning against the union? The impact of the crisis on the Eurosceptic vote in the 2014 European Parliament elections. Electoral Studies, 44(4), 504-514. 
Hooghe, L. and Marks, G. (2017). Cleavage Theory Meets Europe's Crises: Lipset, Rokkan, and the Transnational Cleavage. Forthcoming in Journal of European Public Policy.

Hooghe, L., Marks, G., \& Wilson, C. J. (2002). Does left/right structure party positions on European integration? Comparative Political Studies, 35(8), 965-989.

Kitschelt, H. (1994). The transformation of European social democracy. Cambridge University Press.

Kitschelt, H. \& Rehm, P. (2014) Occupations as a Site of Political Preference Formation. Comparative Political Studies 47(12), 1670-1706.

Kriesi H, Grande E, Lachat R, Dolezal M, Bornschier S and Frey T (2006) Globalization and the transformation of the national political space: Six European countries compared. European Journal of Political Research 45(4), 921956.

Kriesi, H., Grande, E., Lachat, R., Dolezal, M., Bornschier, S., \& Frey, T. (2008). West European politics in the age of globalization. Cambridge: Cambridge University Press.

Kuhn, T., Solaz, H. \& Van Elsas, E. (2017) Putting Your Money Where Your Mouth Is: How Cosmopolitanism Promotes Willingness to Redistribute Across the European Union. Working Paper.

Margalit, Y. (2012). Lost in Globalization: International Economic Integration and the Sources of Popular Discontent. International Studies Quarterly, 56(3), 484-500.

Marks, G., \& Wilson, C. J. (2000). The past in the present: A cleavage theory of party response to European integration. British Journal of Political Science, 30(3), 433-459.

Merton, R. (1968). Social Theory and Social Structure. New York: The Free Press.

Mudde, C., \& Kaltwasser, C. R. (2013). Exclusionary vs. inclusionary populism: Comparing contemporary Europe and Latin America. Government and Opposition, 48(2), 147-174.

Rae Baerg, N., Hotchkiss, J. L. \& Quispe-Agnoli, M. (2017). Documenting the Unauthorized; Political Responses to Unauthorized Immigration.

Forthcoming in Economics and Politics. 
Rodrik, D. (2011). The Globalization Paradox: Democracy and the Future of the World Economy. Cambridge University Press.

Rubin, D. B. (1973). The use of matched sampling and regression adjustment to remove bias in observational studies. Biometrics, 185-203.

Rutte, M. (2017) Aan alle Nederlanders. NRC Handelsblad, 22 januari 2017.

Scheve, K. F., \& Slaughter, M. J. (2001). What Determines Individual TradePolicy Preferences? Journal of International Economics 54(2), 267-92.

Schmitt, H., Hobolt, S. B., Popa, S. A.; Teperoglou, E. (2016) European Parliament Election Study 2014, Voter Study, First Post-Election Survey. GESIS Data Archive, Cologne. ZA5160 Data file Version 4.0.0, doi:10.4232/1.12628

Socialistische Partij, SP (1983) Gastarbeid en Kapitaal. Uitgave Socialistische Partij (https://sptransparent.wordpress.com/gastarbeid-en-kapitaal/).

Tavits, M., \& Potter, J. D. (2015). The effect of inequality and social identity on party strategies. American Journal of Political Science, 59(3), 744-758.

Van Schuur, W. H. (2003). Mokken scale analysis: Between the Guttman scale and parametric item response theory. Political Analysis, 11(2), 139-163.

Vertovec, S., \& Cohen, R. (2002). Introduction: Conceiving Cosmopolitanism. In S. Vertovec \& R. Cohen (Eds.), Conceiving Cosmopolitanism. Theory, Context, and Practices (pp. 1-24). Oxford: Oxford University Press. 